\title{
INFLUENCE OF ORGANOMINERAL FERTILIZATION IN THE DEVELOPMENT OF THE POTATO CROP CV. CUPID
}

\author{
INFLUENNCIA DA FERTILIZAÇÃO ORGANOMINERAL NO DESENVOLVIMENTO \\ DA CULTURA DA BATATA, CV. CUPIDO
}

\begin{abstract}
Ariel Santivañez AGUILAR ${ }^{1}$; Atalita Francis CARDOSO² ; Luara Cristina LIMA $^{3}$; José Magno Queiroz LUZ ${ }^{4}$; Talisson RODRIGUES ${ }^{5}$; Regina Maria Quintão LANA ${ }^{4}$

1. Doutorando em Agronomia na Universidade Estadual Paulista Júlio de Mesquita Filho, Faculdade de Ciências Agronômicas de Botucatu. 2. Professora no Centro Universitário de Goiatuba, Goiatuba, GO, Brasil 3. Doutoranda em Agronomia na Universidade Federal de Uberlândia, Uberlândia, MG, Brasil. lima_luara@ yahoo.com.br; 4. Professores Titulares do Instituto de Ciências Agrárias na Universidade Federal de Uberlândia, Uberlândia, MG, Brasil. 5. Agrônomo pela Universidade Federal de Uberlândia
\end{abstract}

\begin{abstract}
The potato crop is very demanding regarding the presence of nutrients in the form readily available in soil solution and the climatic conditions to ensure satisfactory production of tubers. Each potato cultivar has specific characteristics for its development. The objective of this work was to evaluate the development and productivity of potato cv. Cupid, due to doses of fertilizers and the parceling of organomineral fertilization of the plantation and coverage compared to the use of the mineral. The experiment was conducted in the municipality of Perdizes, in Minas Gerais, in the harvest of 2014/15. The experimental design was in randomized blocks with a factorial scheme of 4 doses x 2 nitrogen managements + control treatment (conventional mineral dose) in 3 replicates. The doses of organomineral fertilizer were: 25, 50, 75 and $100 \%$ of the mineral dose of $600 \mathrm{~kg} \mathrm{ha}^{-1}$ of potassium sulphate, $850 \mathrm{~kg} \mathrm{ha}^{-1}$ monoammonium phosphate, and $300 \mathrm{~kg} \mathrm{ha}^{-1}$ of ammonium sulphate. The management of the fertilization consisted of the achievement or not of the coverage that was made at 19 days after planting (DAP) along with the hilling. At 36, 54, 64 and 81 DAP, collection of plants was performed for the characterization of potato growth. No differences were observed between the doses of organomineral fertilizer as well as in the management of coverage in relation to the use of the mineral. However, the dose of $75 \%$ of the organomineral fertilizer with the realization of coverage provided better physiological response of the plants in relation to the accumulation of dry mass.
\end{abstract}

KEYWORDS: Alternative biofertilizers. Management of coverage. Solanum tuberosum L.

\section{INTRODUCTION}

According to FAO (2015) the potato is produced in an area of 19 million hectares cultivated in 157 countries, with a production of 365 million tons in 2012, being that Brazil has a cultivated area of 135.9 thousand hectares, occupying the 19th place in the world ranking. At the national level, production in the year of 2016 was 3.934 million tons and the production expected for the year 2017 will be 3.986 million tons, in the three harvested crops (IBGE, 2017).

The potato crop is highly responsive to environmental changes, mainly in relation to the fertility of the soil. The potato cultivars for industrial purposes have different responses from the others, due to the accumulation of dry mass in tubers, thus presenting differentiated behavior when it comes to the absorption of nutrients, becoming the focus on obtaining quality raw material and high yield production (BREGAGNOLI et al., 2006).

New technologies have been adopted and added to conventional fertilization, the formulated
NPK aimed at optimizing the use of the soil. The biofertilizers are obtained by mixing organic and mineral fertilizers, should follow the federal legislation of the Ministry of Agriculture, Livestock and Food Supply (MAPA), on the record, minimum guarantees, labels and other aspects. Novais et al. (2007) indicate that the objective of the biofertilizers is to increase the nutrient content of organic materials and the efficiency of mineral fertilizers.

Benefits are promoted by the organic fraction present in the biofertilizers such as: better root development and water retention in the soil; recovery of microbial flora; low propensity to erosion; lower soil acidification, with reduction of the use of limestone; lower operating cost with joint application of organic and mineral product (LEVREIRO, 2009; GONÇALVES et al. 2007).

The effect of a gradual release of nutrients from organomineral fertilizer occurs simultaneously with the development of culture, which makes the agronomic efficiency higher when compared with the mineral fertilizers (KIEHL, 2008). It is relevant 
characteristic provided by the organic fraction of the biofertilizer, the gradual availability of organic compounds in the solution of the soil (LUZ; KORNDÖRFER, 2011). The main advantage of the use of organomineral fertilizer in relation to the mineral is regarding the loss of some nutrients such as nitrogen by volatilization, phosphorus fixation and potassium leaching (SEVERINO et al. 2004).

Hilling is a cultural and traditional practice in the potato crop, which consists in the formation of a ridge of $20 \mathrm{~cm}$ of height at the base of the plants, with the aim of stimulating tuberization of tubers. The majority of potato producers perform the fertilization in cover with application of nitrogen $(\mathrm{N})$ and potassium $(\mathrm{K})$ simultaneously the practice of hilling. The parceling of nitrogen and potassium fertilization in the potato crop is necessary to avoid losses and ensure the supply of nutrients in the adequate time the demand of the plants (VIEIRA; SUGIMOTO, 2002).

In this sense, the objective of this work was to evaluate the development and yield of potato $\mathrm{cv}$. Cupid, as a function of doses of organomineral fertilizer and the parceling of the fertilization of coverage compared to mineral fertilization.

\section{MATERIAL AND METHODS}

The experiment was conducted in Perdizes, Minas Gerais, Brazil $\left(19^{\circ} 21^{\prime} 10^{\prime \prime} \mathrm{S}\right.$ and $\left.47^{\circ} 17^{\prime} 34^{\prime \prime} \mathrm{W}\right)$ and $1000 \mathrm{~m}$ altitude, in the period between December 10, 2014 and March 29, 2015, with the potato cultivar Cupid. The climate is classified as Aw (megathermal), according to the classification of KOPPEN, presenting cold and dry winter and hot and humid summer (Table 1).

Table 1. Precipitation, maximum and minimum temperatures in the region of study.

\begin{tabular}{ccrrrr}
\hline \multirow{2}{*}{ Months } & \multirow{2}{*}{$\begin{array}{c}\text { Precipitation } \\
(\mathrm{mm})\end{array}$} & & \multicolumn{3}{c}{ Day } \\
\cline { 3 - 6 } & & Minimum & Maximum & Minimum & Maximum \\
\hline December & 122.8 & 22.46 & 23.80 & 19.96 & 20.72 \\
January & 97.6 & 24.79 & 26.38 & 20.97 & 22.14 \\
February & 349.2 & 22.16 & 23.55 & 19.50 & 20.33 \\
March & 313.8 & 21.71 & 23.15 & 19.09 & 19.58 \\
\hline
\end{tabular}

Was performed to characterize the experimental area by means of analysis of soil in the $0-20 \mathrm{~cm}$ layer with the following results (Table 2).

Table 2. Soil chemical characterization at 0 to $0.2 \mathrm{~m}$ soil depth

\begin{tabular}{ccccccccccc}
\hline $\mathrm{pH}$ & $\mathrm{P}$ & $\mathrm{K}$ & $\mathrm{Ca}^{2+}$ & $\mathrm{Mg}^{2+}$ & $\mathrm{Al}^{3+}$ & $\mathrm{T}$ & $\mathrm{SB}$ & $\mathrm{OM}$ & $\mathrm{V}$ & $\mathrm{m}$ \\
\hline $\mathrm{H}_{2} \mathrm{O}$ & \multicolumn{2}{c}{$\mathrm{mg} \mathrm{dm}^{-3}$} & & & & $\mathrm{cmol}_{\mathrm{c}} \mathrm{dm}^{-3}$ & & & $\mathrm{~g} \mathrm{dm}^{-3}$ & $\%$ \\
$(1: 2.5)$ & 29.5 & 63.0 & 3.8 & 0.6 & 0.0 & 8.05 & 4.55 & - & 56.0 & 0.0 \\
6.0 & 29 & & & & & & & \\
\hline
\end{tabular}

$\mathrm{pH}$ in $\mathrm{H}_{2} \mathrm{O}, \mathrm{Ca}, \mathrm{Mg}, \mathrm{Al}=\mathrm{KCl}$ solution $\left(1 \mathrm{~mol} \mathrm{~L}^{-1}\right) ; \mathrm{P}, \mathrm{K}=0.05 \mathrm{~mol} \mathrm{~L}^{-1} \mathrm{HCl}+\mathrm{H}_{2} \mathrm{SO}_{4} 0.0125 \mathrm{~mol} \mathrm{~L}^{-1}$; $\mathrm{P}$ available $=$ extractor Mehlich ${ }^{-1}$; $\mathrm{T}=\mathrm{CTC}$ at $\mathrm{pH} 7.0 ; \mathrm{V}=$ saturation of bases; $\mathrm{m}=$ saturation of aluminum, O.M. = organic matter determined by colorimetric method (EMBRAPA, 2011).

The experimental design was in randomized blocks, in a factorial scheme $(4 \times 2+1)$, with eight treatments and a control treatment and three replications, totaling 27 plots. Each plot was constituted by 6 rows, spaced $0.8 \mathrm{~cm}$ between rows, with $6 \mathrm{~m}$ of length, totaling $28.8 \mathrm{~m}^{2}$ of total area per plot.

The treatments consisted of four proportions: $25,50,75$ and $100 \%$ of the dose of the conventional mineral fertilizer in the source and two organomineral fertilization managements: with presence and absence of fertilization of coverage (Table 3). The dose of mineral fertilizer applied at planting was $600 \mathrm{~kg} \mathrm{ha}^{-1}$ of $\mathrm{K}_{2} \mathrm{SO}_{4}\left(50 \%\right.$ of $\left.\mathrm{K}_{2} \mathrm{O}\right)$ and $850 \mathrm{~kg} \mathrm{ha}^{-1}$ of $\mathrm{NH}_{4} \mathrm{H}_{2} \mathrm{PO}_{4}(10 \%$ and $44 \%$ of $\left.\mathrm{P}_{2} \mathrm{O}_{5}\right)$ and $300 \mathrm{~kg} \mathrm{ha}^{-1}$ of $\mathrm{NH}_{2} \mathrm{SO}_{4}(21 \%$ of $\mathrm{N})$, applied in coverage. The doses of organomineral fertilizer applied in treatments with coverage were proportional to the conventional mineral fertilizer dose, which was performed at 19 DAP (days after planting) along with hilling.

Chemical characterization of organomineral fertilizer used in the composition of the treatments listed in Table 4. 
Table 3. Description of the treatments used in the experiment.

\begin{tabular}{ccccc}
\hline \multirow{2}{*}{$\begin{array}{c}\text { of organomineral } \\
\text { fertilizer }\end{array}$} & \multicolumn{4}{c}{ Dose $\left(\mathrm{kg} \mathrm{ha}^{-1}\right)$} \\
\cline { 2 - 5 } & $00-00-30$ & $06-30-00$ & $18-03-00$ & Fertilization of coverage \\
\hline 25 & 240 & 368.3 & 83.5 & $18-03-00$ \\
25 & 240 & 368.3 & - & - \\
50 & 480 & 736.5 & 167 & 83.5 \\
50 & 480 & 736.5 & - & - \\
75 & 720 & 1105 & 250.5 & - \\
75 & 720 & 1105 & - & 250.5 \\
100 & 960 & 1473 & 334 & - \\
100 & 960 & 1473 & - & 334 \\
\hline
\end{tabular}

Table 4. Chemical characterization of organomineral fertilizer.

\begin{tabular}{lccc}
\hline Composition (kg) & $00-00-30+9 \% \mathrm{~S}$ & $06-30-00+6 \% \mathrm{~S}$ & $18-03-00+14 \% \mathrm{~S}$ \\
\hline Organic & 337.57 & 339.27 & 363.61 \\
compound (cake filter) & & & - \\
$\mathrm{KCl}$ & 515.17 & - & 49.86 \\
$\mathrm{NH}_{4} \mathrm{H}_{2} \mathrm{PO}_{4}$ & - & 569.62 & 200 \\
Sulfur Filtered $(70 \% \mathrm{~S})$ & 128.57 & 87.71 & 15.06 \\
Geopeletizador & 18.19 & 5.40 & \\
\hline
\end{tabular}

Soil preparation was performed according to the recommended for the cultivation of potatoes, i.e., one plowing followed by trenching/leveling and, subsequently, the opening of the grooves at a depth of $15 \mathrm{~cm}$. The composition of the treatments followed the following description in Table 4.

The tubers and seeds of the Cupid cultivar used are of class type III (with 30 to 40 millimeters in diameter) and 120 seed tubers were sown per plot.

Plants samples were collected to assess the development of culture, in each collection, two plants of each plot were removed from the second and sixth row. During the cycle, four samples were made: at 36 days after planting (stolonization-DAP), 50 DAP (beginning of tuberization), 64 DAP (growth of the tubers) and 81 DAP (maturation of tubers) (PEREIRA; DANIELS, 2003). For the determination of the dry mass, the stems, leaves and tubers were sectioned and placed in paper bags and dried in an oven with forced air at $65^{\circ} \mathrm{C}$ until reaching a constant mass. After drying, were ground and subjected to chemical determination of nutrients, according to the methodology proposed by Embrapa (2011). We evaluated the leaf contents of macro and micronutrients.

For the characterization of productivity, about 120 days after planting, were harvested tubers of two central lines, eliminating one meter from the end of each plot, having a useful area of $6,4 \mathrm{~m}^{2}$. The tubers were weighed and classified based on two sieves: 45 and $36 \mathrm{~mm}$. Thus, three classifications were established: tubers with a diameter greater than $45 \mathrm{~mm}$ (special), exceeding $36 \mathrm{~mm}(1 \mathrm{x})$ and less than $36 \mathrm{~mm}$ (lollypop). The tubers are damaged by diseases, rotten or deformed by physiological abnormalities known as secondary growth and crack, were separated and constituted a fourth class (discard). Each class was weighed to calculate the productivity of useful area of parcels and estimated $t$ $\mathrm{ha}^{-1}$.

The data obtained were initially tested for normality assumptions of residues (Shapiro-Wilk test), homogeneity among the variances (Levene Test) and additivity of blocks (Additivity) using the SPSS software program (SPSS, 2008). The averages of the treatments were subjected to analysis of variance ( $F$ test), and then compared by the Tukey and Dunnett test with the aid of the statistical program Assistat (SILVA; AZEVEDO, 2009), at $5 \%$ of significance.

\section{RESULTS AND DISCUSSION}

\section{Accumulation of dry mass by the cultivar Cupid}

The doses of organomineral fertilizer did not influence the accumulation of dry mass of stems (DMS) of the cultivar Cupid according to the values obtained in times sampled (Table 5). During the initial stage of development the period of stolonization (36 DAP), the culture was subjected to conditions of water stress for a period of 20 days 
that comprised the first half of January, a period in which there was irregular rains (Table 1). In addition, the physiological response of the tubers subjected to conditions of hydric stress interfered in the reduction of the size of the plants, the number of leaves and stems and reduction in cellular turgor pressure according to reports made by Hsiao (1973) and Hang; Miller (1986).

Table 5. Accumulation of dry mass of stems (DMS) potato cultivar Cupid in different types of fertilizer and management of coverage in the use of fertilizer organomineral.

\begin{tabular}{|c|c|c|c|c|c|c|c|c|}
\hline & \multicolumn{8}{|c|}{$\begin{array}{l}\text { Dry mass of stems } \\
\text { g plant }^{-1}\end{array}$} \\
\hline Time of collection & 36 DAP & & 54 DAP & & 64 DAP & & $81 \mathrm{DAP}$ & \\
\hline \multirow[t]{2}{*}{ Mineral fertilizer } & 2.72 & & 4.44 & & 5.96 & & 6.80 & \\
\hline & \multicolumn{8}{|c|}{ Management of coverage } \\
\hline$\%$ of mineral dose & Without & With & Without & With & Without & With & Without & With \\
\hline 25 & $1.53^{\mathrm{ns}}$ & $2.14^{\mathrm{ns}}$ & $4.318^{\mathrm{ns}}$ & $4.81^{\mathrm{ns}}$ & $5.59^{\mathrm{ns}}$ & $5.88^{\mathrm{ns}}$ & $6.22^{\mathrm{ns}}$ & $7.11^{\mathrm{ns}}$ \\
\hline 50 & $2.18^{\mathrm{ns}}$ & $2.45^{\mathrm{ns}}$ & $4.665^{\mathrm{ns}}$ & $4.69^{\mathrm{ns}}$ & $4.73^{\mathrm{ns}}$ & $6.42^{\mathrm{ns}}$ & $6.57^{\mathrm{ns}}$ & $8.34^{\mathrm{ns}}$ \\
\hline 75 & $3.10^{\mathrm{ns}}$ & $3.06^{\mathrm{ns}}$ & $5.513^{\mathrm{ns}}$ & $5.27^{\mathrm{ns}}$ & $4.94^{\mathrm{ns}}$ & $7.31^{\mathrm{ns}}$ & $8.26^{\mathrm{ns}}$ & $7.72^{\mathrm{ns}}$ \\
\hline 100 & $1.72^{\mathrm{ns}}$ & $1.61^{\mathrm{ns}}$ & $5.345^{\mathrm{ns}}$ & $5.07^{\mathrm{ns}}$ & $6.81^{\mathrm{ns}}$ & $7.47^{\mathrm{ns}}$ & $7.19^{\mathrm{ns}}$ & $9.21^{\mathrm{ns}}$ \\
\hline \multirow[t]{2}{*}{ Average } & $2.13 \mathrm{~A}$ & $2.31 \mathrm{~A}$ & $4.96 \mathrm{~A}$ & $4.96 \mathrm{~A}$ & $5.52 \mathrm{~A}$ & $6.77 \mathrm{~B}$ & $7.06 \mathrm{~A}$ & $8.09 \mathrm{~A}$ \\
\hline & \multicolumn{2}{|c|}{$\begin{array}{c}\text { CV \%=38.62; } \\
\text { DMS }_{\text {DUNNET }}=2.13 ; \\
\text { DMS }_{\text {AC }}=0.76 \\
F=\mathbf{0 . 8 4 ; ~} W=\mathbf{0 . 9 6} ; \\
\mathrm{F}_{\text {Adit }}=\mathbf{0 . 2 6}\end{array}$} & \multicolumn{2}{|c|}{$\begin{array}{c}\text { CV \%=34.51; } \\
\text { DMS }_{\text {DUNNET }}=4.10 ; \\
\text { DMS }_{\text {AC }}=1.46 \\
F=\mathbf{1 . 5 1} ; W=\mathbf{0 . 9 8} ; \\
\mathrm{F}_{\text {Adit }}=\mathbf{0 . 5 7}\end{array}$} & \multicolumn{2}{|c|}{$\begin{array}{c}\text { CV \%=21.77; } \\
\text { DMS }_{\text {DUNNET }}=3.23 ; \\
\text { DMS }_{\text {AC }}=1.15 \\
F=\mathbf{1 . 0 5} ; W=\mathbf{0 . 9 7} \\
\mathrm{F}_{\text {Adit }}=\mathbf{0 . 0 4}\end{array}$} & \multicolumn{2}{|c|}{$\begin{array}{c}\text { CV \%= } 23.34 ; \\
\text { DMS }_{\text {DUNNET }}= \\
4.241 ; \\
\mathrm{DMS}_{\mathrm{AC}}=1.514 \\
F=\mathbf{1 . 3 2} ; W=\mathbf{0 . 9 7} \\
\mathrm{F}_{\text {Adit }}=\mathbf{0 . 6 7}\end{array}$} \\
\hline
\end{tabular}

Averages followed by different letters uppercase within each variable in line differ among themselves by the test of Tukey at 0.05 significance level; ns there shall approve mineral fertilization by the Dunnet test, the 0.05 significance level; F, W, Fadit; Statistics of the Levene test, Shapiro-Wilk test and Tukey's test for additivity of blocks, respectively; values in bold indicate homogeneity of variances, waste with normal distribution and additivity of blocks, respectively, the 0.01 significance level; DAP: days after planting.

At 36 DAP, the doses of organomineral fertilizer did not differ from conventional mineral. Being that they did not have significant differences among themselves (Table 5).

This response can be explained by the process of slow decomposition of the biofertilizers, for which the plant can absorb the nutrients that are readily available. It is worth remembering that conditions of hydric stress followed by intense rain (Table 1) may have contributed for the lower influence of fertilization of coverage in the growth of stems. Medeiros and Cunha (2003) argue that high doses of $\mathrm{N}$ interfere with increasing the development of aerial part and reducing the number of tubers, however the climatic variations modify the growth, development and partitioning of assimilates in potato, besides the possibility of interaction between genotype and environment that can modify the response to doses of $\mathrm{N}$.

\section{Dry mass of leaves along the crop cycle}

For the variable of dry mass of leaves (DML) along the crop cycle, there were no significant differences between treatments (Table 6). Similar results were found by Ferreira (2015) when evaluated the development of potato cv. Agate at 40 and 56 DAP. Camargo (2013) testing potassic fertilizers in cultivar Asterix, observed that at 41 DAP, DML presented an average of 18.98 g plant $^{-1}$, different from that obtained in the stage of stolonization (36 DAP) in the present experiment.

Table 6. Accumulation of dry mass of leaves (DML) potato cultivar Cupid in different types of fertilizer and management of coverage in the use of fertilizer organomineral.

Dry mass of leaves

g plant ${ }^{-1}$

\begin{tabular}{llccc}
\hline $\begin{array}{l}\text { Time of } \\
\text { collection }\end{array}$ & 36 DAP & 54 DAP & 64 DAP & 81 DAP \\
\hline $\begin{array}{l}\text { Mineral } \\
\text { fertilizer }\end{array}$ & 8.88 & 18.84 & 56.16 & 53.88 \\
\hline
\end{tabular}

Management of coverage

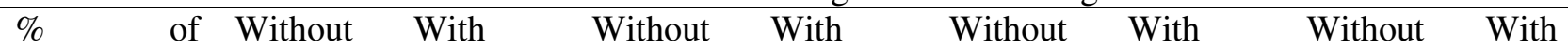




\begin{tabular}{|c|c|c|c|c|c|c|c|c|}
\hline \multicolumn{9}{|l|}{$\begin{array}{l}\text { mineral } \\
\text { dose }\end{array}$} \\
\hline 25 & $5.80^{\mathrm{ns}}$ & $7.90^{\mathrm{ns}}$ & $22.33^{\mathrm{ns}}$ & $22.33^{\mathrm{ns}}$ & $56.17^{\mathrm{ns}}$ & $54.92^{\mathrm{ns}}$ & $55.91^{\mathrm{ns}}$ & $44.11^{\mathrm{ns}}$ \\
\hline 50 & $8.74^{\mathrm{ns}}$ & $8.87^{\mathrm{ns}}$ & $21.46^{\mathrm{ns}}$ & $22.96^{\mathrm{ns}}$ & $35.55^{\mathrm{ns}}$ & $50.71^{\mathrm{ns}}$ & $36.55^{\mathrm{ns}}$ & $62.20^{\mathrm{ns}}$ \\
\hline 75 & $10.30^{\mathrm{ns}}$ & $10.45^{\mathrm{ns}}$ & $25.97^{\mathrm{ns}}$ & $26.13^{\text {ns }}$ & $50.46^{\mathrm{ns}}$ & $62.51^{\mathrm{ns}}$ & $52.20^{\mathrm{ns}}$ & $67.09^{\mathrm{ns}}$ \\
\hline 100 & $6.34^{\mathrm{ns}}$ & $6.36^{\mathrm{ns}}$ & $23.95^{\mathrm{ns}}$ & $29.56^{\mathrm{ns}}$ & $51.22^{\mathrm{ns}}$ & $63.51^{\mathrm{ns}}$ & $41.35^{\text {ns }}$ & $66.17^{\text {ns }}$ \\
\hline Average & $7.79 \mathrm{~A}$ & $8.39 \mathrm{~A}$ & $23.43 \mathrm{~A}$ & $25.24 \mathrm{~A}$ & $48.35 \mathrm{~A}$ & $57.91 \mathrm{~A}$ & $46.50 \mathrm{~A}$ & $59.89 \mathrm{~A}$ \\
\hline & \multicolumn{2}{|c|}{$\begin{array}{c}\text { CV \% }=30.07 ; \\
\mathrm{DMS}_{\mathrm{DUNNET}}=5.968 ; \\
\mathrm{DMS}_{\mathrm{AC}}=2.131 ; \\
\mathrm{F}=\mathbf{0 . 8 6} ; \mathrm{W}=\mathbf{0 . 9 6} ; \\
\mathrm{F}_{\text {Adit }}=\mathbf{0 . 3 3}\end{array}$} & \multicolumn{2}{|c|}{$\begin{array}{c}\text { CV \%=26.79; } \\
\text { DMS }{ }_{\text {DUNNET }}=15.413 ; \\
\text { DMS } \\
\text { F= }=5.504 ; \\
\text { F }_{\text {Adit }}=\mathbf{=}=\mathbf{0 . 5 0}\end{array}$} & \multicolumn{2}{|c|}{$\begin{array}{c}\text { CV \%=26.31; } \\
\text { DMS } \text { DUNNET }=34.122 ; \\
\text { DMS } \\
\text { AC }=12.186 ; \\
\text { F }_{\text {Adit }}=\mathbf{0 . 2 4}\end{array}$} & \multicolumn{2}{|c|}{$\begin{array}{c}\text { CV \%= }=32.35 ; \\
\text { DMS } \\
\text { DMUNNET }=41.798 ; \\
\mathrm{F}=14.927 ; \\
\mathrm{F}_{\mathrm{AC}}=\mathbf{3 . 4 3} ; \mathrm{W}=\mathbf{0 . 9 6} ; \\
\mathrm{F}_{\text {Adit }}=\mathbf{0 . 8 9}\end{array}$} \\
\hline
\end{tabular}

Averages followed by different letters uppercase within each variable in line differ among themselves by the test of Tukey at 0.05 significance level; ns there shall approve mineral fertilization by the Dunnet test, the 0.05 significance level; F, W, Fadit; Statistics of the Levene test, Shapiro-Wilk test and Tukey's test for additivity of blocks, respectively; values in bold indicate homogeneity of variances, waste with normal distribution and additivity of blocks, respectively, the 0.01 significance level; DAP: days after planting.

These lower values probably occurred because of the development hampered in this experiment due to the water stress and unfavorable environmental conditions as already previously commented. The potato is sensitive to water stress, being demanding in water, because it has shallow root system and little branched, it is sensitive to the reduction of assimilates transport from leaves to roots with tendency to closure of the stomata. Therefore, it depends on the adequate supply of water during all stages of plant development, there is a direct correlation between water availability in the soil with the plant development and yield of tubers (FILGUEIRA, 2008).

At 81 DAP at the stage of maturation of the tubers, plots treated with different doses of biofertilizers and without fertilization of coverage presented $46.505 \mathrm{~g}$ plant $^{-1}$ of DML, while with the fertilization of coverage was $59.896 \mathrm{~g} \mathrm{plant}^{-1}$ of DML and where the plots were treated with mineral fertilizer to dry mass of leaves was 53.886 plant $^{-}$ ${ }^{1}$.These values when compared with those obtained by Camargos (2013) that at 86 DAP obtained 34.57 g plant $^{-1}$ and Fernandes (2010) observed at 76 DAP, $25.37 \mathrm{~g} \mathrm{plant}^{-1}$, both studies obtained lower values in relation to the DML but with higher yields than the present work. The vegetative growth exaggerated usually decreases the efficiency of photosynthesis, due to the mutual shading of leaves and also makes the plant to spend more energy with its maintenance, thus reducing the dry mass of tubers.

In research carried out in the harvest of waters by Yorinori (2003), with the cv. Atlantic, was verified higher accumulation of DML in relation to the dry season, being that the maximum accumulation of DML occurred at 79 DAP $(22.67 \mathrm{~g}$ plant $^{-1}$ ) in the harvest of the waters and at 41 DAP $\left(15.5 \mathrm{~g} \mathrm{plant}^{-1}\right)$ in the dry season. Midmore and Prange (1992), establishes that a reduced light intensity causes greater elongation of stems and reduces the size of the leaves, delaying the start of tuberization and senescence of leaves, and also decreases the production of tubers per plant.

The excess water along the productive cycle $(512.37 \mathrm{~mm})$, may have favored a higher incidence of diseases in the area such as late blight (Phytophthora infestans) and early blight (Altenaria solani) and mainly blackleg (Pectobacterium spp.) (Table 1). It is worth mentioning that the cultivar Cupido presents susceptibility to these diseases (HAYASHI, 2001). According to Yorinori (2003) amendments referring to the attack of insects and the incidence of diseases can promote changes in the response of plant development throughout the cycle and affect productivity.

\section{Dry mass of tubers along the crop cycle}

The dry mass of tubers per plant (DMT) did not show significant differences between treatments (Table 7). However, Fernandes (2010) found that from the 55 DAP, there was an accelerated growth in the DMT until around 69 DAP, when the cultivars Atlantic, Asterix, Markies, Agate, and Mondial reached the maximum rates of DMT accumulations was 121.8, 168.1, 120.4, 115.5 and $162.3 \mathrm{~kg} \mathrm{ha}^{-1}$ day $^{-1}$ at $62,67,69,72$ and 75 DAP respectively. 
Table 7. Accumulation of dry mass of the tubers (MST) of potato cultivar Cupid in different types of fertilizer and management of coverage in the use of fertilizer organomineral.

Dry mass of the tubers

g plant ${ }^{-1}$

\begin{tabular}{|c|c|c|c|c|c|c|}
\hline Time of collection & \multicolumn{2}{|c|}{54 DAP } & \multicolumn{2}{|c|}{64 DAP } & \multicolumn{2}{|c|}{81 DAP } \\
\hline Mineral fertilizer & \multicolumn{2}{|c|}{2.99} & \multicolumn{2}{|c|}{29.36} & \multicolumn{2}{|c|}{71.83} \\
\hline & \multicolumn{6}{|c|}{ Management of coverage } \\
\hline$\%$ of mineral dose & Without & With & Without & With & Without & With \\
\hline 25 & $4.22^{\mathrm{ns}}$ & $5.70^{\mathrm{ns}}$ & $28.57^{\mathrm{ns}}$ & $34.40^{\mathrm{ns}}$ & $47.58^{\mathrm{ns}}$ & $50.09^{\mathrm{ns}}$ \\
\hline 50 & $6.08^{\mathrm{ns}}$ & $3.52^{\mathrm{ns}}$ & $21.18^{\mathrm{ns}}$ & $27.77^{\text {ns }}$ & $51.28^{\mathrm{ns}}$ & $80.59^{\text {ns }}$ \\
\hline 75 & $6.65^{\mathrm{ns}}$ & $7.91^{\mathrm{ns}}$ & $28.10^{\mathrm{ns}}$ & $40.22^{\mathrm{ns}}$ & $62.45^{\mathrm{ns}}$ & $71.67^{\mathrm{ns}}$ \\
\hline 100 & $3.66^{\mathrm{ns}}$ & $5.84^{\mathrm{ns}}$ & $35.73^{\mathrm{ns}}$ & $34.89^{\mathrm{ns}}$ & $62.41^{\mathrm{ns}}$ & $84.95^{\mathrm{ns}}$ \\
\hline \multirow[t]{2}{*}{ Average } & $5.11 \mathrm{~A}$ & $5.74 \mathrm{~A}$ & $28.39 \mathrm{~A}$ & $34.32 \mathrm{~A}$ & $55.93 \mathrm{~A}$ & $71.83 \mathrm{~A}$ \\
\hline & \multicolumn{2}{|c|}{$\begin{array}{c}\text { CV \%=70.46; } \\
\text { DMS }_{\text {DUNNET }}=8.84 ; \\
\text { DMS }_{\text {AC }}=3.16 ; \\
\begin{array}{c}F=\mathbf{2 . 3 5} ; W=\mathbf{0 . 9 6} ; F_{\text {Adit }} \\
=\mathbf{0 . 9 4}\end{array}\end{array}$} & \multicolumn{2}{|c|}{$\begin{array}{c}\text { CV \%= 28.58; } \\
\mathrm{DMS}_{\mathrm{DUNNET}}=21.584 ; \\
\mathrm{DMS}_{\mathrm{AC}}=7.708 ; \\
F=\mathbf{1 . 5 3} ; W=\mathbf{0 . 9 4} ; \\
\mathrm{F}_{\text {Adit }}=\mathbf{2 . 2 8}\end{array}$} & \multicolumn{2}{|c|}{$\begin{array}{c}\text { CV \%= 28.56; } \\
\text { DMS }_{\text {DUNNET }}=44.85 ; \\
\text { DMS }_{\text {AC }}=16.01 ; \\
F=6.340 ; W=0.87 ; \\
\mathrm{F}_{\text {Adit }}=\mathbf{0 . 2 1}\end{array}$} \\
\hline
\end{tabular}

Averages followed by different letters uppercase within each variable in line differ among themselves by the test of Tukey at 0.05 significance level; ns there shall approve mineral fertilization by the Dunnet test, the 0.05 significance level; F, W, Fadit; Statistics of the Levene test, Shapiro-Wilk test and Tukey's test for additivity of blocks, respectively; values in bold indicate homogeneity of variances, waste with normal distribution and additivity of blocks, respectively, the 0.01 significance level; DAP: days after planting.

Is was found that the accumulation of dry mass in the Asterix tubers was small at the beginning of tuberization, followed by accelerated growth between 55 and 69 DAP, similar to the present study with Cupid where the accelerated growth was between 50 and 64 DAP. The cv. Asterix showed a maximum accumulation at 97 DAP (166.68 g plant $^{-1}$ ) while cv. Cupid at 81 DAP (Table 7). The DMT of the Cupid cultivar in the maturity stage of the tubers was 71.83 and $63.87 \mathrm{~g}$ plant $^{-1}$ when submitted to mineral and organomineral fertilization, respectively, with lower values than 50\% compared to varieties Asterix and Mondial, working of Fernandes (2010).

The achievement or not of the fertilization of coverage and the different doses of organomineral fertilizer, did not influenced the DMT (Table 7). Normally the parceling of fertilization with $\mathrm{N}$ is favorable, as in the work of Mallman (2001) who noted that the parceling of $\mathrm{N}\left(80 \mathrm{~kg} \mathrm{ha}^{-1}\right.$ of $\mathrm{N}$ before planting and the remaining in coverage, performed at 30 days after planting) and higher doses of $\mathrm{K}$ (480 $\mathrm{kg} \mathrm{ha}^{-1}$ and $960 \mathrm{~kg} \mathrm{ha}^{-1}$ of $\mathrm{K}_{2} \mathrm{O}$ ) for the cultivar Monalisa increased the content of dry mass of the tubers, as well as high doses of $\mathrm{K}$ and $\mathrm{P}$, combined with $\mathrm{N}$ and $\mathrm{S}$, promoted better quality of tubers.

However, in conditions less favorable for the potato as high temperatures and rainfall greater than required (Table 1), Marouelli (2005) affirms that the excess water is harmful, because it hinders the tubers respiration, reduces the aeration of the soil and favors the multiplication of soil pathogens and during the period of emission of stolon and early tuberization have greater potential for the formation of hollow heart especially in large tubers, can cause secondary growth (secondary growth) and cracks in the tubers. Excessively wet soil causes the opening of the lenticels, also called lenticellose and, as this opening allows the entry of pathogens, the tuber becomes more susceptible to infections (DE BOER, 2008).

On the other hand, Doorenbos and Kassan (2000) argue that the occurrence of a small period of water deficit in the stadium of stolonization (beginning of the formation and growth of the tubers) results in the obtaining of small tubers and this was precisely what occurred in the present study.

\section{Productivity and classification of tubers}

Productivity showed no significant differences between the doses of organomineral fertilization and the achievement or not of the fertilization of coverage (Table 8). The average productivity with doses of organomineral fertilizer was $16 \mathrm{t} \mathrm{ha}^{-1}$ and $18.5 \mathrm{t} \mathrm{ha}^{-1}$ with mineral fertilization, both below the productivity average in Brazil, which is $27.80 \mathrm{tha}^{-1}$, according to data from IBGE (2015). 
Table 8. Total yield of tubers $\left(\mathrm{t} \mathrm{ha}^{-1}\right)$ of potato cv. Cupid, depending on the doses of nitrogen organomineral fertilization and management of coverage, with respect to mineral fertilization

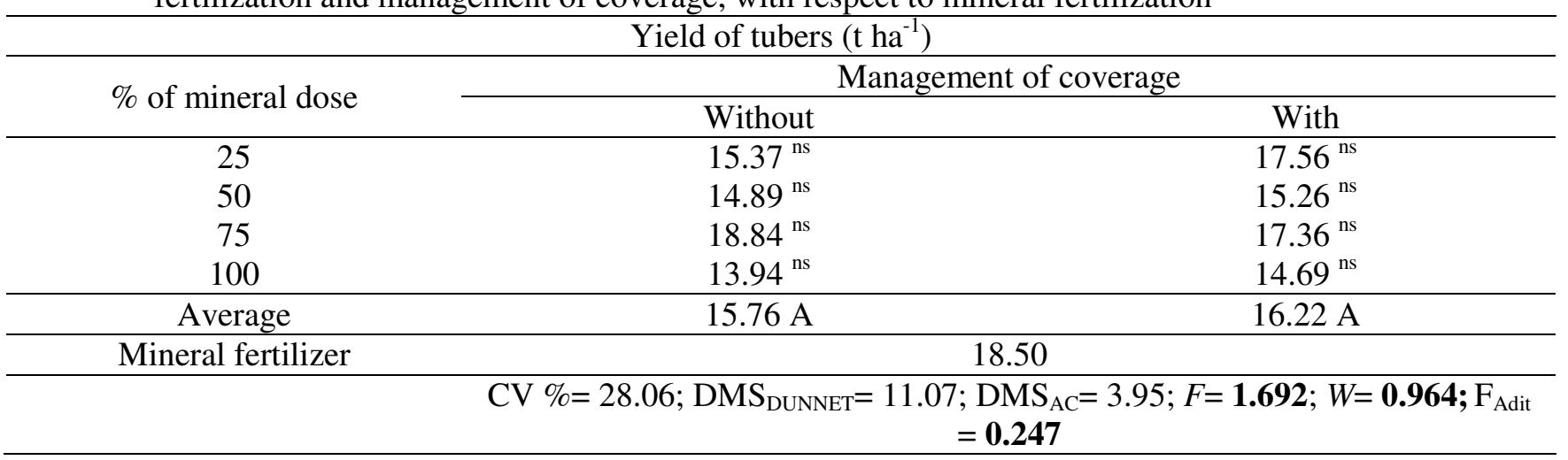

Averages followed by different letters uppercase within each variable in line differ among themselves by the test of Tukey at 0.05 significance level; ns there shall approve mineral fertilization by the Dunnet test, the 0.05 significance level; F, W, Fadit; Statistics of the Levene test, Shapiro-Wilk test and Tukey's test for additivity of blocks, respectively; values in bold indicate homogeneity of variances, waste with normal distribution and additivity of blocks, respectively, the 0.01 significance level; DAP: days after planting.

The occurrence of nighttime temperatures higher this season increases the breathing with consequent reduction in production, in addition to pressure of diseases be greater due to the occurrence of rainfall. According to Wrege et al. (2005), the cold temperature at night collaborates for the plant to reduce its respiration and thus accumulate more reserves, the accumulation of reserves in the tuber stems, depending on the amount of energy that the plant assimilates during the day, makes it breath less.

The fact that low doses of organomineral fertilizer were equal in productivity with mineral fertilization (Table 8), can be attributed to the organic fraction present in the composition of these fertilizers that gives them gradual solubility, i.e., the total content is not fully soluble in water, causing the nutrients to be released gradually over time, at the beginning with lower availability (LUZ; KORNDÖRFER, 2011; SEVERINO et al., 2004). Kiehl (2008) affirms that the biofertilizer feature gradual solubilization fertilizers during the period of development of culture, which makes the agronomic efficiency greater when compared with mineral fertilizers.

Table 9. Classification of tubers in $\mathrm{t} \mathrm{ha}^{-1}$ of $\mathrm{cv}$. Cupid, depending on the doses of nitrogen organomineral fertilization and management of coverage, with respect to mineral fertilization

\begin{tabular}{|c|c|c|c|c|c|c|c|c|}
\hline Class & \multicolumn{2}{|l|}{ Special } & \multicolumn{2}{|l|}{$1 \mathrm{X}$} & \multicolumn{2}{|l|}{ Lollipop } & \multicolumn{2}{|l|}{ Discard } \\
\hline \multirow[t]{2}{*}{ Mineral fertilizer } & 4.78 & & 5.05 & & 1.71 & & 4.28 & \\
\hline & \multicolumn{8}{|c|}{ Management of coverage } \\
\hline$\%$ of mineral dose & Without & With & Without & With & Without & With & Without & With \\
\hline 25 & $5.10^{\mathrm{ns}}$ & $5,70^{\mathrm{ns}}$ & $5.12^{\mathrm{ns}}$ & $4.52^{\mathrm{ns}}$ & $1.58^{\mathrm{ns}}$ & $1.25^{\mathrm{ns}}$ & $3.55^{\mathrm{ns}}$ & $6,09^{\mathrm{ns}}$ \\
\hline 50 & $5.02^{\mathrm{ns}}$ & $4,53^{\mathrm{ns}}$ & $4.56^{\mathrm{ns}}$ & $2.92^{\mathrm{ns}}$ & $1.38^{\mathrm{ns}}$ & $1.50^{\mathrm{ns}}$ & $3.92^{\mathrm{ns}}$ & $6,30^{\mathrm{ns}}$ \\
\hline 75 & $6.81^{\mathrm{ns}}$ & $4,67^{\mathrm{ns}}$ & $5.41^{\mathrm{ns}}$ & $2.95^{\mathrm{ns}}$ & $1.41^{\mathrm{ns}}$ & $0.75^{\mathrm{ns}}$ & $5.19^{\mathrm{ns}}$ & $8,98^{\mathrm{ns}}$ \\
\hline 100 & $3.17^{\mathrm{ns}}$ & $5,20^{\mathrm{ns}}$ & $4.19^{\mathrm{ns}}$ & $4.50^{\mathrm{ns}}$ & $2.12^{\mathrm{ns}}$ & $0.63^{\mathrm{ns}}$ & $4.45^{\mathrm{ns}}$ & $4,35^{\mathrm{ns}}$ \\
\hline \multirow[t]{2}{*}{ Average } & $5.02 \mathrm{~A}$ & $5,02 \mathrm{~A}$ & $4.82 \mathrm{~A}$ & $3.72 \mathrm{~A}$ & $1.62 \mathrm{~A}$ & $1.03 \mathrm{~A}$ & $4.28 \mathrm{~A}$ & $6,43 \mathrm{~B}$ \\
\hline & \multicolumn{2}{|c|}{$\begin{array}{l}\text { CV \%= } 57.06 ; \\
\mathrm{DMS}_{\mathrm{DUNNET}}=6.92 ; \\
\mathrm{DMS}_{\mathrm{AC}}=2.47 ; \\
F=\mathbf{2 . 0 8} ; W=\mathbf{0 . 9 8} ; \\
\mathrm{F}_{\text {Adit }}=\mathbf{0 . 2 6}\end{array}$} & \multicolumn{2}{|c|}{$\begin{array}{l}\text { CV \%= } 51.99 ; \\
\text { DMS }_{\text {DUNNET }}=5.49 \\
\mathrm{DMS}_{\text {AC }}=1.96 ; \\
F=\mathbf{2 . 7 1 ;} W=\mathbf{0 . 9 6} ; \\
\mathrm{F}_{\text {Adit }}=\mathbf{0 . 0 4}\end{array}$} & \multicolumn{2}{|c|}{$\begin{array}{l}\text { CV \%= }=48.52 ; \\
\mathrm{DMS}_{\mathrm{DUNNET}}=1.61 ; \\
\mathrm{DMS}_{\mathrm{AC}}=0.57 ; \\
F=\mathbf{0 . 7 6} ; W=\mathbf{0 . 9 8} ; \\
\mathrm{F}_{\text {Adit }}=\mathbf{0 . 0 4}\end{array}$} & \multicolumn{2}{|c|}{$\begin{array}{l}\mathrm{CV} \%=33.19 ; \\
\mathrm{DMS}_{\mathrm{DUNNET}}= \\
4.45 ; \\
\mathrm{DMS}_{\mathrm{AC}}=1.59 ; \\
F=\mathbf{2 . 3 5} ; W=\mathbf{0 . 9 4} ; \\
\mathrm{F}_{\text {Adit }}=\mathbf{1 . 9 5}\end{array}$} \\
\hline
\end{tabular}

Averages followed by different letters uppercase within each variable in line differ among themselves by the test of Tukey at 0.05 significance level; ns there shall approve mineral fertilization by the Dunnet test, the 0.05 significance level; F, W, Fadit; Statistics of the Levene test, Shapiro-Wilk test and Tukey's test for additivity of blocks, respectively; values in bold indicate homogeneity of variances, waste with normal distribution and additivity of blocks, respectively, the 0.01 significance level; DAP: days after planting.

The parceling of phosphorus with or without cover with organomineral fertilizer did not significantly influence in the standings of the tubers Special types and 1X (Table 9). On the other hand, 
researchers such as Vieira and Sugitomo (2002) found higher yields in areas where nitrogen and potassium were divided into two applications (planting and hilling), in comparison to the area where the $\mathrm{N}$ and $\mathrm{K}$ were supplied in a single application, along with the phosphorus in the furrow at planting.

Boock and Catani (1956) observed an increase in the productivity of potato, mainly in years with high rainfall when they did the parceling of nitrogen and potassium fertilization, subdividing the nutrients three times. In the study developed by Mallmann (2001) in which were evaluated doses of $\mathrm{N}, \mathrm{P}$ and $\mathrm{K}$ and split applications of $\mathrm{N}\left(80 \mathrm{~kg} \mathrm{ha}^{-1}\right.$ of $\mathrm{N}$ at sowing $+40 \mathrm{~kg} \mathrm{ha}^{-1}$ of $\mathrm{N} 30$ days after planting) and ( $80 \mathrm{~kg} \mathrm{ha}^{-1}$ of $\mathrm{N}$ at sowing $+80 \mathrm{~kg} \mathrm{ha}^{-1}$ of $\mathrm{N} 30$ days after planting) cv. Monalisa, noted that there was greater productivity in the treatments submitted to the parceling. However, these studies were exclusively with mineral fertilizer.

Regarding lollipop classification, the absence of nitrogen of coverage was higher $(1.62 \mathrm{t}$ $\mathrm{ha}^{-1}$ ) when it was done the fertilization of coverage at 19 DAP $\left(1.03 \mathrm{t} \mathrm{ha}^{-1}\right)$, being the highest harmful value, because this type of tuber is the lowest value in the market (Table 9).

In general, it was obtained a high percentage of discard with respect to overall productivity, with the two types of fertilizers and split in side dressing fertilization (Table 9) due to adverse environmental conditions especially the high precipitation index in the phase of filling of the tubers as previously mentioned. High severity occurred from blackleg (Pectobacterium spp.) which directly influenced the rot of tubers, being the main cause of discard. This disease begins by injury or by Lenticels, combining with favorable conditions of high temperature and high humidity, moves quickly, with curtains at the boundary between the affected tissues and healthy in the pulp in the tubers, followed by secondary invasion of organisms that cause the rotting of the tissues normally associated with an unpleasant odor due to these.

The environmental conditions during the growth and development of the tubers drastically affect the dormancy period of the same at high temperatures and photoperiod growing, typical of spring cultivation, shorten the dormancy of the tubers, accelerating the physiological aging of tubers and reducing the time of storage, reducing the commercial quality on the market (BISOGNIN; STRECK, 2009).

In excessively humid soils, the symptoms in infected tubers are aggravated by the action of other anaerobic bacteria present in the soil, reducing the number of tubers suitable for the market (LOPES; QUEZADO, 2001).

The harvest of water represents more than $50 \%$ of the production of tubers and is characterized by the high cost of production because of the pressure of diseases, in the case of the winter harvest, yields are higher and characterized with technological packages superior to the production in the harvest of the waters complementary irrigation (CEPEA, 2013).

Cardoso (2014) in the evaluation of different doses of biofertilizer in potato cultivar Atlantic in two seasons (water and winter) observed a greater quantity of classification discard in the harvest of the waters, with an average of $2.43 \mathrm{t} \mathrm{ha}^{-1}$ and in more favorable conditions for the culture (winter) the discard decreases in a $39.5 \%$ to $0.96 \mathrm{t} \mathrm{ha}^{-1}$, even though the values shown in table 8 are higher, being $4.28 \mathrm{t} \mathrm{ha}^{-1}$ when the plots were treated with mineral fertilizer and did not differ with the doses of organomineral fertilizer. Already without the fertilization of coverage was of $4.28 \mathrm{t} \mathrm{ha}^{-1}$ and was $6.43 \mathrm{t} \mathrm{ha}^{-1}$. The principle there is an explanation for the fact of using the fertilization of coverage led to higher average value of discard. Already without the fertilization of coverage was $4.28 \mathrm{t} \mathrm{ha}^{-1}$ and with was $6.43 \mathrm{t} \mathrm{ha}^{-1}$. There is no explanation for the fact that using the fertilization of coverage led to higher average discard value. The coefficients of variation, which are indicative of the experimental precision, were high (Table 9) with respect to the classification and yield of tubers, when compared to those found by Silva et al. (2006); Costa et al. (2007); Bisognin et al. (2008) and the coefficient of variation at a maximum of $22.70 \%$, considering that the yield of tubers is a quantitative character and of great environmental influence (SILVA et al., 2006).

Environmental factors such as rainfall, temperature and photoperiod influenced negatively the development and productivity of the crop. Higher temperatures, as in the case of the experiment favored the growth of the aerial part and a reduction in the production of tubers (BISOGNIN et al., 2008; HELDWEIN et al., 2009).

Menezes et al. (2001) assert that temperatures above ideal can prevent the onset of tuberization or reduce the rate of development, especially during the period of filling of tubers. The culture presents a good development under conditions of temperate climate, being that the ideal temperatures vary between 18 and $22^{\circ} \mathrm{C}$. The thermoperiodicity required by the crop varies between 20 and $25^{\circ} \mathrm{C}$ of diurnal temperatures, and the nocturnal ones from 10 to $12^{\circ} \mathrm{C}$. According to Van Dam et al. (1996) may not occur the formation 
of tubers when night temperatures exceed $20^{\circ} \mathrm{C}$, short days are required to trigger the onset of tuberization and long days or neutral for flowering.

\section{CONCLUSION}

In conditions of high rainfall in the absence of the ideal thermoperiodicity for the development of the potato crop, the lower doses $(25 \%)$ of organomineral fertilizer without importing the parceling of the fertilization of coverage had equal effect as higher doses $(50,75,100 \%)$ of
Organomineral fertilizer and mineral fertilization in the development and productivity of tubers.

Due to the high rate of discard among all treatments it is difficult to affirm an organomineral dose to be recommended, being necessary more studies to establish an economic-commercial dose.

\section{ACKNOWLEDGMENT}

For financial support and scholar grants we are grateful to CAPES (Coordination for the Improvement of Higher Education Personnel).

RESUMO: A cultura da batata é muito exigente quanto à presença de nutrientes na forma prontamente disponível na solução do solo e as condições climáticas para garantir produção de tubérculos satisfatória. Cada cultivar de batata possui características específicas ao seu desenvolvimento. O objetivo do trabalho foi avaliar o desenvolvimento e produtividade de batata cv. Cupido, em função de doses de fertilizante organomineral e o parcelamento da adubação de plantio e cobertura comparado ao uso do mineral. O experimento foi conduzido no município de Perdizes, em Minas Gerais, na safra das águas de 2014/2015. O delineamento experimental foi em blocos ao acaso, com esquema fatorial de 4 doses x 2 manejos da adubação + tratamento controle (dose mineral convencional) em 3 repetições. As doses de fertilizante organomineral foram: $25,50,75$ e $100 \%$ da dose mineral que foi de $600 \mathrm{~kg} \mathrm{ha}^{-1}$ de sulfato de potássio, $850 \mathrm{~kg} \mathrm{ha}^{-1}$ fosfato monoamônico, e $300 \mathrm{~kg} \mathrm{ha}^{-1}$ de sulfato de amônio. Os manejos da adubação consistiram da realização ou não da cobertura que foi feita aos 19 dias após o plantio (DAP) junto com a amontoa. Aos 36, 54, 64 e 81 DAP, foi realizada coleta de plantas para a caracterização do crescimento da batateira. Não foram verificadas diferenças entre as doses do fertilizante organomineral bem como no manejo da cobertura deste em relação ao uso do mineral. No entanto, a dose de $75 \%$ do fertilizante organomineral com a realização da cobertura proporcionou melhor resposta fisiológica das plantas em relação ao acúmulo de massa seca.

PALAVRAS-CHAVE: Solanum tuberosum, manejo da cobertura, fertilizantes alternativos organominerais.

\section{REFERENCES}

BISOGNIN, D. A.; STRECK, N. A. Desenvolvimento e manejo das plantas para alta produtividade e qualidade da batata. Associação Brasileira da Batata, Itapetininga, 2009.

BISOGNIN, D. A.; MULLER, D. R.; STRECK, N. A.; ANDRIOLO, J. L.; SAUSEN, D. Desenvolvimento e rendimento de clones de batata na primavera e no outono. Pesquisa Agropecuária Brasileira, Brasília, v. 43, p. 699-705, 2008. https://doi.org/10.1590/S0100-204X2008000600005

BOOCK, O. J.; CATANI, R. A. Adubação da batatinha: Resultados preliminares referentes ao emprego do parcelamento de N e K. Bragantia, Campinas, v. 15, n. 26, p. 353-361, nov. 1956.

https://doi.org/10.1590/S0006-87051956000100026

BREGAGNOLI, M; BREGAGNOLI, F. C. R.; MINAMI, K.; GRATIERI, L. A.; MINCHILLO, M. Análise bromatológica de sete cultivares de batata cultivadas na safra de verão no Sul de Minas Gerais. Horticultura Brasileira, Brasília, v.21, p.384-387, 2003.

CAMARGOS, R. O. Acúmulo de nutrientes, produtividade e qualidade de batata, cv. Asterix, sob fontes de fertilizantes potássicos. 2013. 89 f. Dissertação (Mestrado em Fitotecnia) - Curso de Pós-graduação em Agronomia, Universidade Federal de Uberlândia, Uberlândia, 2013. 
CARDOSO, A. F. Fertilizante organomineral em batata, cv. Atlantic: Produtividade, crescimento e acumulo de nutrientes em diferentes safras de plantio. 2014. $184 \mathrm{f}$. Tese (Doutorado em Fitotecnia) - Curso de Pós-graduação em Agronomia, Universidade Federal de Uberlândia, Uberlândia, 2014.

CEPEA - Centro de Estudos Avançados em Economia Aplicada. Indicadores do preço da batata. Ago. 2013. Disponível em: http://cepea.esalq.usp.br/hfbrasil/edicoes/126/batata.pdf . Acesso em: 12 de janeiro de 2018.

COSTA, L. C.; BISOGNIN, D. A.; ANDROLO, J. L.; RITER, C. E. L.; BANDINELLI, M. G. Identificação de clones de batata com potencial para mesa e adaptados para os cultivos de outono e primavera do Rio Grande do Sul. Ciência e Natura, Santa Maria, v. 29, n. 2, p. 93-104, 2007.

DE BOER, S.H. Managing soft rot and ring rot. In: JOHNSON, D. A. (Ed.). Potato health management. 2nd ed. Saint Paul: The American phytopathological society, 2008. chap.18 p.171-182.

DOORENBOS, J.; KASSAM, A. H. Efeitos da água no rendimento das culturas. Estudos FAO Irrigação e Drenagem 33. Universidade Federal da Paraíba, Paraíba. 2000. 191p.

EMBRAPA - Empresa Brasileira de Agricultura e Pecuária. Manual de análise de solo. $2^{\mathrm{a}}$. Ed. Rio de Janeiro, RJ, Brasil. Embrapa Solos, 2011. 230p.,

FAO - Food and agriculture organization of the united nations. FAOSTAT. Disponível em: http://faostat.fao.org/site/339/default.aspx . Acesso em: 10 de novembro de 2015.

FERNANDES, A. M. Crescimento, produtividade, acúmulo e exportação de nutrientes em cultivares de batata (Solanum tuberosum L.). 2010. 144 f. Dissertação (Mestrado em Agronomia) - Faculdade de Ciências Agronômicas, Universidade Estadual Paulista “Júlio Mesquita”, Botucatu, 2010.

FERREIRA, D. M. Produção e qualidade de batata cultivar Ágata sob adubação mineral e organomineral. 2015. 94 f. Dissertação (Mestrado em Agronomia) - Universidade Estadual do Sudoeste da Bahia, Vitória da Conquista.

FILGUEIRA, F. A. R. Novo manual de olericultura: agrotecnologia moderna na produção e comercialização de hortaliças. 2 ed. Universidade Federal de Viçosa, Viçosa, 2008. 421p.

GONÇALVES M. V.; CARREON, R.; LUZ, J. M. Q.; GUIRELLI, J. E.; SILVA, P. A. R.; SILVA, M. A. D. Produção de batata, cv. Atlantic, submetida a produtos organominerais Aminoagro. In: ENCONTRO NACIONAL DA PRODUÇÃO E ABASTECIMENTO DE BATATA, 13. 2007. Anais eletrônicos. Associação Brasileira da Batata, Holambra. 2007. Disponível em: http://www.abbabatatabrasileira.com.br/batatashow4/resumos.htm. Acesso em: 23 de março de 2017.

HANG, A. N.; MILLER, D. E. Yield and physiological responses of potatos to deficit, high frequency sprinkler irrigation. Agronomy Journal, Madison, v. 78, p. 436-440, 1986.

https://doi.org/10.2134/agronj1986.00021962007800010004x https://doi.org/10.2134/agronj1986.00021962007800010003x https://doi.org/10.2134/agronj1986.00021962007800030008x

HAYASHI, P. Variedade Cupido. Nova opção para mercado freso. 2001. Itapeteninga. Batata Show. Disponível em: http://www.abbabatatabrasileira.com.br/revista03_010.htm. Acesso em 07 de setembro de 2015.

HELDWEIN, A. B.; STRECK, N. A.; BISOGNIN, D. A. Batata. In: MONTEIRO, J. E. B. A. Agrometeorologia dos cultivos: o fator meteorológico na produção agrícola. Brasília: Instituto Nacional de Meteorologia, 2009. cap. 2, p. 281-293. 
HSIAO, T. C. Plant responses to water stress. Annual review of plant physiology, Rockville Pike, v. 24, n. 1, p. 519-570, 1973.

IBGE - INSTITUTO BRASILEIRO DE GEOGRAFIA E ESTATÍSTICA. Levantamento sistemático da produção agrícola. Disponível em:

http://www.ibge.gov.br/home/estatistica/indicadores/agropecuaria/lspa/lspa_201704_5.shtm. Acesso em 20 de maio de 2017.

IBGE - INSTITUTO BRASILEIRO DE GEOGRAFIA E ESTATÍSTICA. Levantamento sistemático da produção agrícola. Disponível em: . Acesso em: 07 de novembro de 2017

KIEHL, E. J. Fertilizantes organominerais. 4. ed. Piracicaba, SP: DEGASPARI, 2008. 160 p.

LEVRERO, C. R. Fertilizante organomineral: a serviço do mundo. In: FÓRUM ABISOLO, 2009.

LOPES, C. A.; QUEZADO, A. M. Podridão-mole e canela-preta da batata. 2001. Batata Show, Itapeteninga. Disponível em: http://www.abbabatatabrasileira.com.br/revista03_006.htm. Acesso em 12 setembro de 2017.

LUZ, P. H. de C.; KORNDÖRFER, G. H. Reciclagem de subprodutos na agricultura. In: VASCONCELOS, H. P. (Ed.). Contribuições para a produção de alimentos: Ideias para uma agricultura eficaz. São Paulo: Nova Bandeira Produções Editoriais, 2011. v. 1, p. 123-143.

MALLMANN, N. Efeito da adubação na produtividade, qualidade e sanidade de batata cultivada no centro-oeste paranaense. 2001. 129 p. Dissertação (Mestrado em Agronomia). Universidade Federal do Paraná, Curitiba, Paraná, 2001.

MAROUELLI, W. A. Irrigar bem. Um dos segredos para reduzir doenças e aumentar o lucro do bataticultor. 2005. Batata Show, Itapeteninga. Disponível em: http://www.abbabatatabrasileira.com.br/revista11_010.htm. Acesso em 07 de sep. de 2015.

MEDEIROS, C. A. B.; CUNHA, B. P. Cultivo hidropônico de sementes pré-básicas de batata: concentração de nitrogênio na solução nutritiva. Horticultura Brasileira, Brasília, v. 21, n. 2, p. 372, 2003.

MENEZES, C. B. de; PINTO, C. A. B. P.; NURMBERG, P. L.; LAMBERT, E. S. Combining ability of potato genotypes for cool and warn seasons in Brazil. Crop Breeding and applied Biotecnology, Viçosa, v. 1, n. 1, p. 145-157, 2001.

MIDMORE, D. J.; PRANGE, R. K. Growth response of two Solanum species to contrasting temperatures and irradiance levels: relation to photosynthesis, dark respiration and chlorophyll flurescence. Annals of Botany, Londres, v. 69, n. 1, p. 13-20, 1992. https://doi.org/10.1093/oxfordjournals.aob.a088300

NOVAIS, R. F.; SMYTH, T. J.; NUNES, F. N. Fósforo. In: NOVAIS, R. F.; et al. (Eds.) Fertilidade do solo. Sociedade Brasileira de Ciência do Solo, Viçosa, 2007. cap. 8, p. 472537.

PEREIRA, A. S.; DANIELS, J. O cultivo da batata na região sul do Brasil. Brasília: EMBRAPA, 2003. 567 p.

SEVERINO, L. S.; COSTA, F. X.; BELTRÃO, M. E.; LUCENA, M. A.; GUIMARÃES, M. M. B.

Mineralização da torta de mamona, esterco bovino e bagaço de cana estimada pela respiração microbiana.

Revista de Biologia e Ciências da Terra, Campina Grande. v. 5, n. 1, p. 1-5, 2004.

SILVA, F. De A. S.; AZEVEDO, C. A. V. De. Principal Components Analysis in the Software AssistatStatistical Attendance. In: WORLD CONGRESS ON COMPUTERS IN AGRICULTURE, 7, Reno-NVUSA: American Society of Agricultural and Biological Engineers, St. Joseph, 2009. 
SILVA, G. O.; SOUZA, V.Q.; PEREIRA, A. da S.; CARVALHO, F. I. F.; NETO, R. F. Early generation selection for tuber appearance affects potato yield components. Crop Breeding and Applied Biotechnology, Viçosa, v. 6, n. 1, p. 73-78, 2006.

SPSS v. 17.00 SPSS. Chicago, Illinois, 2008. CD-ROM.

VAN DAM, J.; KOOMAN, P. L.; STRUIK, P. C. Effects of temperature and photoperiod on early growth and final number of tuber in potato (Solanum tuberosum L.) Potato Research, Edinburgh, v. 39, p. 51-62, 1996. https://doi.org/10.1007/BF02358206

VIEIRA, F. de C.; SUGITOMO, L. H. Importância da adubação na cultura da batata. Batata Show, Itapeteninga, v. 2, n. 5, p. 16-17, set. 2002.

WREGE, M. S.; PEREIRA, A. da S.; HERTER, F. G. Climas das principais regiões produtoras de batata do Brasil. Batata Show: A revista da batata, Itapetininga, SP, n. 11, 2005.

YORINORI, G. T. Curva de crescimento e acúmulo de nutrientes pela cultura da batata cv. 'Atlantic' 2003. 66 f. Dissertação (Mestrado em Agronomia), Escola Superior de Agricultura "Luiz de Queiroz" Universidade de São Paulo, Piracicaba, 2003. 